\title{
Grandparenting Membentuk Karakter Anak Usia Dini di Masa Pandemi Covid-19
}

\author{
Lia Dwi Ayu Pagarwati ${ }^{\natural}$, Arif Rohman ${ }^{2}$ \\ Pendidikan Anak Usia Dini, Universitas Negeri Yogyakarta \\ DOI: $\underline{10.31004 / o b s e s i . v 5 i 2.831}$
}

\begin{abstract}
Abstrak
Tujuan penelitian ini memaparkan bagaimana grandparenting membentuk tanggung jawab, jujur, mandiri, disiplin dan religius anak di masa pandemi covid-19. Penelitian ini menggunakan penelitian kualitatif dengan metode studi kasus. Pengumpulan data menggunakan wawancara dan angket (googleform). Wawancara yang digunakan adalah wawancara mendalam. Partisipan dalam penelitian ini nenek yang mengasuh cucunya sebanyak 6 keluarga. Penelitian dilakukan di 5 kabupaten Provinsi Sumatera Selatan. Hasil penelitian menunjukkan penyerahan pengasuhan pada nenek terjadi akibat beberapa faktor yaitu perceraian, kematian dan waktu bekerja orang tua. Pola pengasuhan yang di gunakan nenek dalam membetuk karakter tanggung jawab, jujur, disiplin, mandiri dan religius berupa pengasuhan yang otoriter, otoritatif dan permissive dengan metode penjelasan, pemberian contoh dan pembiasaan. Dalam pola asuh yang digunakan nenek berdampak baik dalam membentuk karakter berupa disiplin, tanggung jawab, jujur, religius dan mandiri pada cucu mereka. Dengan terbentuknya karakter anak dengan baik maka dalam membiasakan anak dalam menerapkan protokol kesehatan dengan hidup bersih dan sehat juga berjalan dengan baik pula.
\end{abstract}

Kata Kunci: grandparenting; pendidikan karakter; anak usia dini; pandemi covid-19

\begin{abstract}
The purpose of this study is to describe how grandparenting forms the responsibility, honesty, independence, discipline and religion of children during the Covid-19 pandemic. This research uses qualitative research with a case study method. Data collection using interviews and questionnaires (googleform). The interview used is an in-depth interview. Participants in this study were 6 families who care for their grandchildren. The research was conducted in 5 districts of South Sumatra Province. The results showed that the delivery of care to the grandmother occurred due to several factors, namely divorce, death and parents' working time. The parenting patterns used by grandmothers to form responsible, honest, disciplined, independent and religious characters are in the form of authoritarian, authoritative and permissive parenting with methods of explanation, giving examples and habituation. The parenting style used by grandmothers has a good impact in shaping character in the form of discipline, responsibility, honesty, religion and independence for their grandchildren. With the formation of children's character properly, in familiarizing children in implementing health protocols by living a clean and healthy life, it also goes well.
\end{abstract}

Keywords: Grandparenting, Character Education, Early Childhood, the Covid-19 Pandemic

Copyright (c) 2020 Lia Dwi Ayu Pagarwati, Arif Rohman

$\triangle$ Corresponding author:

Email Address: liadwi.2019@student.uny.ac.id (Air sugihan, Ogan Komering Ilir, Sumatera Selatan)

Received 21 October 2020, Accepted 31 October 2020, Published 4 November 2020 


\section{PENDAHULUAN}

Lingkungan keluarga merupakan lingkungan utama bagi anak untuk belajar mengenai norma, nilai, sikap, dan kepercayaan budaya mereka sehingga anak-anak tumbuh menjadi anak yang memiliki sikap positif untuk bertindak dalam lingkungan yang lebih luas setelahnya (Muncsh (2016)). Dalam menanamkan hal tersebut, keluarga memiliki tokoh penting yang berperan yaitu kedua orang tua dan keluarga besar (kakek nenek, paman, bibi dan saudara lainnya) dan keduanya saling mempengaruhi satu sama lain (Lasota, 2015).

Mengingat pentingnya dari lingkungan keluarga bagi perkembangan anak, orang tua pastinya dalam merawat atau mengasuh anak memiliki cara atau pola pengasuhan tersendiri agar anaknya tumbuh menjadi anak yang pintar, cerdas serta memiliki budi pekerti yang baik dalam menghadapi berbagai situasi. Untuk itu dalam keluarga harus adanya pembagian peran dari setiap anggota keluarga. Dimana ayah sebagai kepala keluarga yang mencari nafkah dan ibu yang akan merawat anak dan mengurus pekerjaan rumah atau juga bisa sebaliknya untuk bertukar peran. Kerja sama antar suami istri sangat di perlukan dalam hal tersebut (Santoso \& Fahrinnia, 2018)

Di Indonesia sendiri, terdapat beranekaragam jenis kondisi keluarga. Terutama pada daerah perkotaan yang padat dengan penduduk yang mana orang tua harus meninggalkan rumah dan menyerahkan pengasuhan anak pada pembantu (babysister). Dan biasanya apabila kondisi seperti itu terjadi pada daerah pedesaan yang mengharuskan orang tua untuk merantau dengan waktu yang cukup lama sosok ibu atau ayah digantikan oleh anggota keluarganya seperti kakek dan nenek atau orang tua dari orang tua anak. Dalam hal ini, hasil survei yang dilakukan oleh Sumargi et al., (2015) tentang pengasuhan orang tua di Indonesia menunjukkan dari 210 orang tua dimana $37 \%$ nya pengasuhan anak di serahkan kepada kakek dan nenek selama orang tua bekerja. Selain kondisi ekonomi, perceraian dan kematian orang tua juga merupakan alasan bagi anak untuk diasuh oleh kakek dan nenek. Yang mana usia anak pada saat orang tua nya bercerai berada pada usia yang masih tergolong muda untuk mengalami keadaan dari ketidak utuhannya keluarga (Arini, 2018).

Hal tersebut sejalan dengan penelitian yang dilakukan (Wellard, 2011) mengenai penyerahan pengasuhan kepada kakek nenek dan hasil penelitian menunjukka faktor-faktor yang menjadi alasan menga kakek nenek mengasuh cucu yaitu mencakup orang tua dengan masalah penyalahgunaan narkoba atau alkohol, penyakit mental, kekerasan dalam rumah tangga dan penelantaran anak. Dan diperkuat oleh penelitain yang dilakukan Saxena \& Sean, (2019) mengenai faktor yang menjadi alasan mengapa kakek nenek mengasuh cucu atau anak dari anak mereka yaitu orang tua anak mengalami kecanduan alkohol atau obat-obatan, orang tua memiliki masalah pada kesehatan mental atau masalah emosional, penelantaran anak, pengabaian atau pelecehan, orang tua di penjara, pengalaman orang tua (kehamilan remaja, dll.), masalah kesehatan fisik atau kematian orang tua, kehidupan rumah tangga yang tidak stabil, tunawisma, kekurangan sumber daya keuangan, kurangnya kemampuan umum, kekerasan dalam rumah tangga di rumah, perceraian, tantangan keluarga lainnya dan penempatan militer. Berperannya salah satu orang tua mengahruskan orang tua harus bekerja keras dalam menghidupi anaknya meskipun harus meninggalkan anak dan diasuh oleh kakek dan nenek.

Pengasuhan yang dilakukan oleh kakek dan nenek (grandparenting) ini indentik dengan pengasuhan yang selalu memanjakan atau membebaskan kemauan cucu mereka yang disebut dengan pengasuhan permisive. Dimana pola pengasuhan permissive ini menurut Bamrid dalam Gafor \& Kurukkan, (2014) mencerminkan perlakukan kehangatan dan kasih sayang, penegakan wewenang dan aturan yang rendah, unsur penerimaan yang tinggi, mengambil peran sebagai teman dari pada induk, membiarkan anak membuat keputusan sendiri dan sangat minimal sekali dalam menggunakan hukuman. Dengan begitu akan menyebakan anak lebih dekat dengan kakek dan neneknya dibandingkan dengan orang tuanya (Eriyanti et al., 2019). Hal tersebut sama dengan penelitian yang dilakukan oleh Khadijahalavi et al., (2016) tentang pengasuhan kakek nenek pada cucu dan hasil dari 
penelitian menunjukkan sebagian besar responden menggunakan pola pengasuhan yang digunakan adalah pengasuhan permisif ; Enam responden menampilkan pola pengasuhan seperti orang tua anak, lima responden menampilkan pola pengasuhan otoriter, empat responden menampilkan pola pengasuhan budaya keluarga dan dua responden yang menggunakan gaya persahabatan dan lebih dari satu menggunakan gaya pengasuhan.

Pola pengasuhan permissive ini merupakan pengasuhan yang sangat berpengaruh dalam perilaku anak (Santrock dalam Yun et al., (2019)). Dimana perilaku tersebut akan tercermin pada nilai karakter anak yang dibentuk pada lingkungan anak. Untuk anak yang di asuh oleh kakek nenek, tentunya itu akan menjadi tugas bagi kakek nenek untuk menanamkan karakter pada cucu. Nilai karakter yang di maksud adalah 1) Religius, 2) Jujur, 3) Toleransi, 4) Kerja Keras, 5) Kreatif, 6) Mandiri, 7) Demokratis, 8) Disiplin, 9) Bersahabat/ Komunikatif, 10) Rasa Ingin Tahu, 11) Menghargai Prestasi, 12) Gemar Membaca, 13) Semangat Kebangsaan, 14) Cinta Tanah Air, 15) Cinta Damai, 16) Peduli Lingkungan, 17) Peduli Sosial, dan 18) Tanggung Jawab (Cahyono, 2017). Pada masa pandemi covid-19 sekarang mengharuskan segala aktivitas dilakukan di rumah, sehingga peluang waktu yang dihabiskan kakek nenek sangat besar utuk bersama cucu mereka. Namun kakek nenek juga harus memperhatikan protokol kesehatan seperti memakai masker, mencuci tangan sebelum dan sesudah melakukan aktivitas atau memegang benda-benda, berjemur, berolahraga dan makan-makan yang bergizi yang ditetapkan pemerintah mengingat penjangkit terbesar dari virus covid-19 tersebut adalah kakek nenek (Sary, 2020). Pesan moral yang terkandung di masa pademi ini sangat tinggi bagi semua orang termasuk anak. Budaya hidup bersih harus disampaikan dan melakukan pembiasaan harus diterapkan pada anak. Untuk itu kakek nenek berperan menanamkan karakter anak dalam kehidupan sehari-hari. Karakter yang ditanamkan pada anak bisa berupa rasa tanggung jawab, jujur, disiplin, mandiri dan religius. Seperti penelitian yang dilakukan (Purandina \& Winaya, 2020) mengenai karakter yang bisa diterapkan pada anak di rumah dan hasil menunjukkan terdapat beberapa karakter yaitu (1) Nilai karakter religius, (2) Nilai karakter disiplin, (3) Nilai karakter kreatif, (4) Nilai karakter mandiri, (5) Nilai karakter tanggung jawab, dan (6) Nilai karakter rasa ingin tahu. Tentunya berkembangnnya nilai karakter sebut tidak terlepas dari kerjasama semua anggota keluarga.

Dari hasil wawancara yang dilakukan, peneliti menemukan anak yang diasuh oleh nenek dengan memiliki karakter berbeda yaitu anak memiliki sikap mandiri dan disiplin dalam kehidupan sehari-hari bersama kakek neneknya. Hal tersebut sejalan dengan penelitian yang dilakukan oleh Latifah et al. (2016) mengenai pengaruh pengasuhan nenek pada aspek kemandirian anak yang hasilnya menunjukkan anak-anak yang diasuh nenek memiliki perkembangan kemandirian dan disiplin yang baik. Sama halnya dengan penelitian yang dilakukan oleh Breheny et al., (2013) dalam penelitiannya menunjukkan bahwa pengasuhan oleh kakek nenek tidak selamanya memiliki pengaruh negatif terhadap perkembangan anak, hal tersebut ditinjau dari cara kakek nenek mengasuh apabila kakek nenek secara profesional dalam melakukan pengasuhan maka hasilnya akan positif terutama pada aspek kemandirian dan kedisiplinan. Namun hal tersebut bertolak belakang dengan penelitian yang dilakukan oleh Edwards, (2018) bahwa anak yang diasuh oleh kakek nenek akan memiliki sikap yang lebih negatif dibandingkan dengan anak yang diasuh bersama dengan orangtua. Hasil penelitian tersebut diperkuat oleh (Putri et al., 2020) tentang pembentukan kemandirian anak yang di asuh oleh grandparent menunjukkan pengasuhan yang dilakukan oleh kakek nenek menggunakan pengasuhan permissive yang mana tindakan yang dilakukan oleh kakek dan nenek membuat anak akan tidak rajin dalam usaha mencapai sesuatu, mudah menyerah, lebih banyak menuntut pemuasan segera tanpa usah yang sungguh-sungguh, suka mengandalkan orang lain, kurang memiliki rasa tanggung jawab, menimbulkan permasalahan emosi dan perilaku anak, suka merengek bahkan merajuk hingga keinginannya terpenuhi. Pola asuh seperti ini akan membentuk pribadi yang kurang baik bagi anak dan juga sangat mempengaruhi pada karakter anak yaitu kemandirian anak dimana jika 
perkembangan kemandirian anak dari usia dini tidak dibentuk dengan baik tentunya akan sangat mempengaruhi untuk kehidupan anak dimasa mendatang.

Dari beberapa hasil penelitian yang dilakukan sebelumnya pastinya pengasuhan kakek dan nenek memiliki dampak yang bersifat positif dan negative. Dari penelitian sebelumnya telah membahas pengasuhan kakek nenek pada aspek kemandirian dan disiplin anak dengan latar belakang penyerahan pengasuhan kepada kakek nenek adalah orang tua bekerja, belum adanya latar belakang lain. Oleh karena itu peneliti bertujuan untuk mengaji lebih dalam faktor yang melatar belakangi pengasuhan nenek, pola asuh nenek dalam membentuk karakter berupa tangung jawab, jujur, disiplin, mandiri dan religius pada anak, pegetahuan kakek nenek tentang virus covid-19, dan cara nenek mengajarkan anak untuk mematuhi ptotokol kesehatan dari pemerintah dengan cara hidup bersih dan sehat. Oleh karena itu judul yang diangkat dalam penelitian ini adalah "Grandparenting Membentuk Karakter Anak Usia Dini Di Masa Pandemi Covid-19".

\section{METODOLOGI}

Peneliti menggunakan metode penelitian kualitatif dengan pendekatan studi kasus. Dengan begitu, akan diperoleh sebuah informasi berupa grandparenting membentuk tanggung karakter anak di masa pandemi covid -19. Responden berjumlah 6 nenek dengan rentang usia 50-58 tahun yang memiliki latar belakang pendidikan mulai dari SD, SMP, SMA dan S1 berada di wilayah kabupaten yang ada di Provinsi Sumatera Selatan. Anak laki-laki berjumlah dua orang anak dan empat anak perempuan dengan rentang usia anak 5-6 tahun yang diasuh oleh nenek. Wawancara diperluas berdasarkan referensi terkait dan dilakukan secara mendalam.

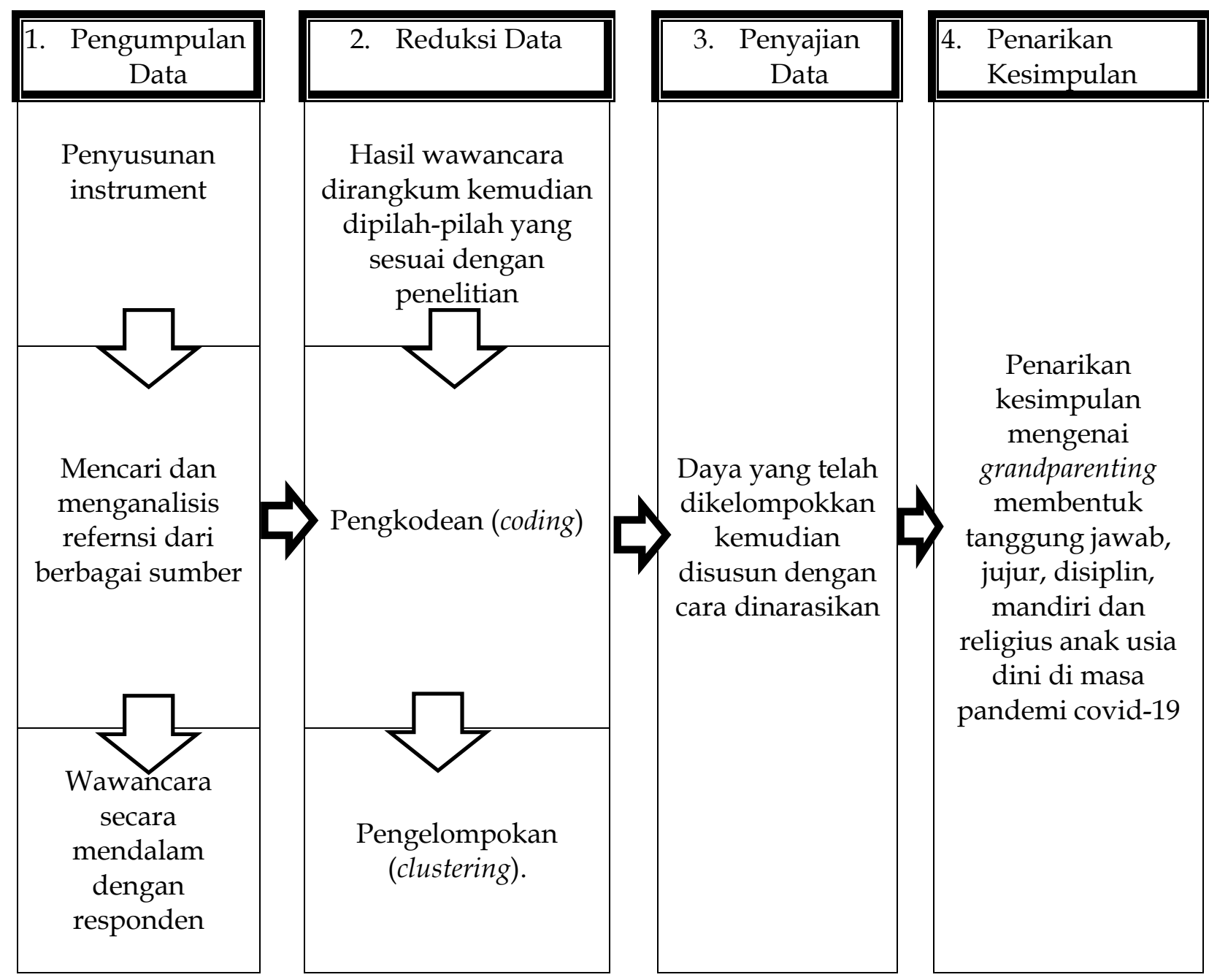

Gambar 1. Langkah-langkah Penelitian Model Milles and Huberman 
Data primer didapat dari wawancara mendalam yang dilakukan bersama nenek dan data sekunder didapat dari analisis referensi dan beberapa artikel tentang pengasuhan membentukan tanggung jawab, jujur, disiplin, mandiri dan religius anak. Dalam penyusunan instrument yang digunakan untuk mengumpulkan informasi mengenai grandparenting membentuk tanggung jawab, jujur, mandiri, disiplin dan religius dimasa pandemi covid-19 peniliti mengadopsi dari sebuah penelitian yang dilakukan oleh Ristia (2016) dan Sary (2020) peneliti terdahulu menggunakan 2 domain pertanyaan yang digunakan untuk mendapatkan informasi sedangkan peneliti menambah 1 domain tersebut menjadi 3 yaitu 1) latar belakang pengasuhan $\mathrm{Cucu}, 2)$ cara pengasuhan nenek untuk membentuk karakter berupa tanggung jawab, jujur, disiplin, mandiri dan religius dan 3) pengetahuan nenek mengenai virus corona (covid-19). Alur dari penelitian ini terdapat pada Gambar 1.

Data yang didapat dari nenek yang mengasuh cucunya yang berusia 5-6 tahun dengan latar belakang pengasuhan yang berbeda-beda. Penelitian dilakukan di 5 kabupaten wilayah Provinsi Sumatera Selatan. Pemilihan kabupaten menggunakan teknik purposive sampling yaitu berdasarkan tujuan penelitian yang ingin dicapai. Kabupaten yang terpilih adalah kabupaten Ogan Komering Ilir (OKI), kabupaten Ogan Komering Ulu (OKU), kabupaten Ogan Komering Ulu Timur (OKUT), Kabupaten Ogan Komering Ulu Selatan (OKUS) dan Kabupaten Ogan Ilir (OI) yang sesuai dengan tujuan penelitian. Peneliti menemukan responden yang sesuai dengan kriteria penelitian yaitu melalui informasi dari guru yang mengajar TK di daerah masing dan meminta nomor telephone dari guru. Dalam situasi pandemi seperti ini, peneliti dalam melakukan wawancara menggunakan panggilan video whattshapp dan juga panggilan telephone dikarenakan 5 daerah kabupaten tersebebut jauh dari daerah tempat tinggal peneliti. Dalam proses panggilan video whattshapp nenek dibantu oleh anggota keluarga lainnya. Sebelumnya, peneliti meminta izin terlebih dahulu kepada masing-masing responden terkait melibatkan keluarga dalam penelitian yang dilakukan. Responden yang mengizinkan mengisi kuesioner singkat berupa biodata responden menggunakan google forms. Dalam pengisisan data, nenek dipandu oleh peneliti dan dibantu oleh keluarga lainnya. Setelah selesai, maka peneliti mulai melakukan wawancara mendalam dengan menggunakan bahasa Indonesia melalui panggilan video whattshapp dengan waktu dari setiap orang bekisar 60 menit dihari yang berbeda dan semua wawancara direkam secara audio.

\section{HASIL DAN PEMBAHASAN}

Penelitian ini mendeskripsikan informasi mengenai faktor yang melatar belakangi penyerahan pengasuhan kepada nenek, grandparenting membentuk karakter berupa tanggung jawab, jujur, disiplin, mandiri dan religius anak, pengetahuan nenek tentang virus covid-19, dan cara nenek mengajarkan anak untuk mematuhi protokol kesehatan dari pemerintah dengan cara hidup bersih dan sehat. Hasil wawancara yang dilakukan dari 6 responden akan di jelaskan dengan pembahasan sebagai seberikut.

\section{Latar Belakang Pengasuhan Cucu}

Hasil penelitian menunjukkan bahwa terkait latar belakang pengasuhan cucu mereka memiliki alasan yang berbeda-beda yang mana (N1 \& N6) dikarenakan kedua orang tua cucu bercerai diusia cucu masih 2 tahun dan sekarang cucu diasuh oleh orang tua dari pihak ayah (N1). Untuk cucu (N6) orang tua bercerai ketika anak berusia 1 tahun dan cucu sekarang diasuh oleh orang tua dari pihak ibu. Untuk biaya hidup cucu ditanggung oleh orang tua si anak dan ((N1) \& (N6). (N2, N3 dan N4) memiliki alasan yang sama yaitu dikarenakan orang tua cucu sibuk bekerja. Untuk biaya hidup cucu ditanggung oleh kedua orang tua cucu. (N5) dikarenakan orang tua cucu (ibu) meninggal dunia diusia cucu berusia 3 tahun, jadi cucu diasuh orang tua dari pihak ibu dan ayahnya mengasuh adik dari si anak yang diasuh nenek. Untuk biaya hidup cucu di tanggung oleh (N5) dan ayahnya. 
Teori ekologi menejelaskan bawa anak akan mulai berinteraksi sosial dengan lingkungan terdekat di sekitarnya sehingga orang terdekat di keluarga diharapkan dapat membantu dalam pelaksanaan pengasuhan pada anak ketika orang tuanya bekerja agar pengasuhan anak tetap berlangsung optimal. Di Indonesia, fenomena pengasuhan oleh nenek menjadi pilihan bagi para orang tua yang bekerja. Keikutsertaan nenek dalam mengasuh cucu merupakan salah satu bentuk dukungan pada keluarga yang orang tuanya bekerja. Grandparenting merupakan suatu hal yang biasa terjadi di Indonesia seperti sudah menjai kebudayaan dari nenek moyang yang turun menurun (Fauziningtyas et al., 2019).

\section{Grandparenting Membentuk Tanggung jawab, Jujur, Displin, Mandiri, dan Religius Anak}

Hasil penelitian menunjukkan bahwa (N1-N6) dalam pola asuh yang digunakan untuk pembentukan karakter cucunya berupa sikap disiplin, jujur, tanggung jawab, mandiri dan religius, disini nenek menggunakan pola pengasuhan otoriter, otoritatif dan permsivie. Untuk menanamkan karakter tanggungjawab, displin dan religius kepada cucu mereka, (N1,N2, N4 dan N6) menggunakan pola asuh otoritatif yang mana nenek bersikap hangat namun tegas kepada cucu agar anak mau mengerjakan tugas sekolah atau belajar terlebih dahulu sebelum melakukan aktivitas bermain dan nenek memberikan contoh yang baik terlebih dahulu agar cucu mau menuruti yang diperintahkan neneknya. Sedangkan pola asuh ototriter digunakan untuk aktivitas seperti melakukan kegiatan sholat, mengaji, makan, kebersihan tubuh (mandi dan gosok gigi) yaitu dengan cara menjelakan kepada cucu kegiatan tersebut merupakan kewajiban bagi setiap umat muslim untuk dilakukan dan apabila tidak dilakukan akan mendapatkan dosa. Selain itu, (N1, N2, N4 dan N6) juga mengajak cucu untuk ikut mempraktikkannya agar nantinya cucu terbiasa. Sama seperti pendapat Salafuddin et al., (2020) dalam menanamkan karakter tanggung jawab dan religius yang bisa dilakukan yaitu dengan mengajari dan membiasakan anak untuk mempersiapkan keperluannya sendiri misalnya menyiapkan keperluan sekolah dan membiasakan anak untuk membantu pekerjaan rumah nenek. Anak boleh bermain bersama siapa saja tetapi untuk waktu bermain harus ada batasan karena anak memiliki aktivitas lain seperti sekolah TPA, mengaji dan belajar itu salah satu cara supaya anak dapat bertanggung jawab terhadap tugasnya. Sama halnya dengan karakter relegius, nenek merupakan orang yang sangat berperan dalam memberi contoh atau teladan pada cucu mereka misalnya mengajak anak untuk pergi kemushola sebelum kumandang adzan maghrib melakukan aktivitas mengaji hingga menjelang isya.

(N1, N2, N4 dan N6) melakukan hal tersebut bertujuan agar cucu terbiasa melakukan hal tersebut tanpa disuruh atau dikomando terlebih dahulu. Seperti halnya menurut (Santi, 2016) dalam menjalani proses habituasi yang baik, akan sangat bagus jika dilakukan dengan pembiasaan sehari-hari. Pembentukan karakter anak salah satunya memiliki rasa tanggung jawab yaitu melalui peneladanan, pencontohan dan pembiasaan pola-pola disiplin. Maka jika anak terbiasa melakukan pola-pola disiplin yang melatih kesadaran bertanggung jawab, maka anak akan merasakan dalam menjalani dan menampilkan sikap dan perilaku itu sebagai suatu kebutuhan. Karakter sikap disiplin akan memiliki rasa tanggung jawab dan rasa tanggung jawab akan dilakukan dengan sikap disiplin yang dimiliki seseorang. Hal tersebut akan membawa seseorang tersebut pada locus of control yang dimilikinya. Dimana menghasilkan keberhasilan pada penyesuaian diri yang positif dan keberhasilan dalam tiap tahap perkembangannya anak secara optimal. Dengan begitu, bisa dikatakan ada kaitannya antara pembentukan sikap tanggung jawab, disiplin dan religius.

Sedangkan (N3 dan N5) menggunakan pola asuh permisivie dalam menanamkan karakter tanggung jawab, displin dan religius kepada cucu mereka, disini nenek membolehkan anak bermain sebelum pekerjaan tugas sekolah atau belajar selesai, bersifat hangat dan tidak tegas dalam aturan yang telah dibuat. Dimana disini nenek memberikan apa yang dimau oleh cucu, tidak menggunakan hukuman atau paksaan dan membiarkan cucu melakukan apa yang dia inginkan., dengan mempertimbangkan cucu masih terlalu kecil jika terlalu dipaksa untuk mengikuti aktivitas orang dewasa. Namun, disini nenek masih 
mengajak anak pada aktivitas sehari-hari tetapi jika anak tidak mau melakukannya tidak apaapa. Seperti halnya hasil penelitian yang telah dilakukan oleh (Susanti, 2017) terdapat pengaruh yang signifikan antara pola asuh permisivie dengan kedisiplinan. Yang menyebabkan adanya pengaruh yaitu apabila semakin tinggi pola asuh permisif maka semakin rendah kedisiplinan anak. Berdasarkan hasil dari perhitungan determinasi, diketahui kedisiplinan 31,24\% dipengaruhi oleh pola asuh permisif sedangkan $68,76 \%$ dipengaruhi oleh faktor lain.

Pada pembentukan karakter anak berupa sikap jujur dan mandiri, (NI-N6) menggunakan pola asuh otoriter, otoritatif. Dimana (N1-N6) dalam menanamkan sikap jujur nenek menggunakan pola asuh otoriter seperti pada saat melihat cucu membawa mainan yang bukan milik mereka pulang disini nenek akan menanyakan kepada cucunya main tersebut milik siapa dan cucu bilang milik mereka tetapi setelah ditelusuri dan terbukti mainan tersebut bukan milik sang cucu dan pemilik maianan tersebut tidak tahu jika maianan tersebut dibawa oleh si cucu maka disini nenek menjelaskan kepada cucu hal tersebut merupakan tindakan yang tidak terpuji sama halnya dengan mencuri hak milik orang lain maka sang nenek menuyuruh cucu untuk mengembalikan mainan tersebut dan meminta maaf kepada temannya dan ketika ingin meminjam cucu harus meminta izin terlebih dahulu sebelum mengambilnya. Seperti menurut Samiaji, (2019) Pada dasarnya anak usia dini belum paham mengenai arti dari konsep kepemilikan, sehingga disini wajar jika anak belum mengerti yang mana miliknya dan yang mana milik orang lain. Anak disini dalam berfikir masih menggunakan pola pikir yang bersifat konkret fungsional dan egosentris maka anak akan menganggap atau mengklaim semua yang menurutnya menarik adalah miliknya. Untuk itu, perlunya pengajaran untuk anak dalam hal berempati kepada orang lain sejak dini. Atau pada saat cucu mengerjakan tugas sekolah tidak boleh bohong kalau tugasnya sudah selesai padahal belum selesai begitu juga ketika sedang makan anak tidak boleh bilang kalau makanannya sudah habis tetapi pada kenyataanya makanan tersebut habis karena dibuang. Dari hal kecil seperti itu cucu diajarkan untuk jujur dalam kehidupan sehari-hari agar anak memiliki karakter sikap jujur yang tertanam dari cucu kecil dan untuk bekal cucu di kehidupan dewasa nantinya.

Sedangkan untuk pembentukan sikap mandiri kepada cucu, (NI-N6) menggunakan pola asuh otoritatif yang mana disini awalnya nenek memberikan arahan dan contoh untuk aktivitas ringan seperti memakai baju, mandi, makan, memakai sepatu, cuci piring dengan tujuan agar anak terbiasa melakukan aktivitas tersebut seiring bertambah usia cucu.

Seperti penelitian yang dilakukan oleh Fono et al., (2019) yang hasilnya menunjukkan pola pengasuhan nenek juga berpengaruh pada sikap kemandirian cucu mereka. Pengasuhan yang bersifat baik maka akan menghasilkan sikap dan perilaku cucu yang baik pula. Pengasuhan nenek tidak selamanya memberikan potensi yang kearah negative. Cucu yang diasuh oleh nenek juga bisa hidup mandiri sama halnya dengan anak yang diasuh oleh kedua orangtuanya. Hal tersebut sejalan dengan pendapat Suwito dalam Nurlatifah et al., (2020) dalam proses menerapkan pendidikan karakter kepada anak pada lingkungan keluarga merupakan hal yang tidak bisa mengabaikan dari peran sosok kakek-nenek. Mereka mempunyai peran vital pada kehidupan cucu mereka. Pengaplikasian peran tersebut dilaksanakan melalui menjalankan tugas-tugas instrumental dan simbolik, meliputi semua bantuan praktis seperti; pemeliharaan anak, dukungan finansial, dan (dalam beberapa kasus) perumahan. Selain itu, semua anggota keluarga bisa memberikan pengaruh yang berarti dalam pengembangan karakter anak.

\section{Pengetahuan Nenek Terkait Virus Corona (Covid-19)}

Setiap hari Penderita dan kasus kematian yang diakibat oleh infeksi virus Corona terus meningkat. Sejauh ini, virus tersebut banyak memakan korban pada orang yang sudah lanjut usia (lansia) dibandingkan pada orang dewasa atau anak-anak. Total sementara hingga saat ini, virus mematikan tersebut telah menjangkit lebih dari 100.000 manusia penduduk dunia. 
Dengan 4.000 jiwa orang dinyatakan meninggal dunia. Survey menyatakan kematian terbanyak itu terjadi pada penderita yang memiliki berusia 80 tahun. Badan kesehatan dunia WHO (World Health Organization) dan CDC (Centers for Disease Control) melaporkan bahwa usia pra-lansia (kisaran umur 50-59 tahun) angka kematian menyentuh angka $2 \%$, kisaran umur 60-69 tahun dengan jumlah 4 dan naik dua kali lipat menjadi $8 \%$ dan angka $15 \%$ menunjukkan pada kisaran umur 70 tahun. Persentase paling memuncak yaitu 21,9\% terjadi pada kisaran umur 80 tahun (kemenkes 23-04-2020).

Hal tersebut di perkuat dengan ada himbauan bagi kakek nenek untuk sementara waktu kakek-nenek disarankan untuk mengisolasi diri secara fisik dari cucu, karena tidak memungkinkan untuk melakukan pengasuhan kepada cucu mereka. Anda berada di garis depan untuk keluarga Anda setiap hari (Delap et al., 2020).

Dalam menyikapi hal tersebut, sangat pentingnya pengetahuan yang dimiliki oleh lansia mengenai corona (covi-19). Dari hasil penelitian, (N1-N6) menyatakan mengetahui akan adanya virus corona sejak akhir tahun 2019 melalui berita yang awalnya terjadi di China. Dan untuk di Indonesia sendiri pada bulan februari 2020 dikarenakan adanya warga Indonesia yang berstatus positf terinfeksi virus tersebut. (N1-N6) juga mengetahui apa saja gejala orang yang terjangkit virus tersebut seperti demam, sesak napas dan sakit tenggorokan.

Dalam memutus tali rantai penularan dan persebaran virus (N1-N6) mengetahui bahwa dalam keseharian harus menerapkan protocol kesehatan seperti mencuci tangan, memakai masker, makan makanan yang bergizi, menghindari kerumunan dan berjemur. Mengingat virus tersebut sangat rentan pada lansia, nenek yang mengasuh cucu mau tidak mau harus ketat dalam menerapkan protocol kesehatan (Alyami, 2020).

Dan juga nenek sangat perlu menjelaskan kepada cucu mereka mengenai virus corona tersebut agar mau menerapkan protocol kesehatan dari pemerintah. Dari hasi penelitian (N1N5) menginformasikan bahwa mereka sudah menjelaskan mengenai virus tersebut dan harus mematuhi protocol kesehatan yaitu dengan cara memberikan contoh dan mengajak anak untuk memakai masker, selalu mencuci tangan sebelum dan sesudah melakukan aktivitas diluar maupun di dalam rumah. Sama halnya dengan penelitian yang dilakukan oleh Suprapto et al., (2020) mengenai pembiasaan cuci tangan yang baik dan benar, hasil penelitian menunjukkan dalam pembiasaan mencuci tangan sesuai standar WHO dapat berhasil jika menggunakan tiga langkah yaitu cermah atau penjelasan, pemberian contoh bisa berupa video dan praktik langsung dengan keadaan air mengalir. Sama halnya seperti yang dianjurkan salah satu satgas Covid-19 Ikatan Dokter Anak Indonesia (IDAI) Yogi Prawira dalam (Sulistyawati \& Murdaningsih, 2020) mengatakan, anak bisa diajarkan untuk memakai masker yang benar yaitu dengan menutup alat pernapasan anak yaitu hidung dan mulut. Sering kali untuk menarik minat anak memakai masker keluarga menggunaka masker yang memiliki animasi-animasi lucu, meskipun begitu, kita juga perlu memperhatikan bahan dasar dari masker tersebut agar sesuai dengan protocol kesehatan dan harus sesuai petunjuk WHO. Satgas menyarankan durasi penggunaan satu masker yaitu maksimal empat jam.

Satgas juga mengakui memang tidak mungkin untuk anak yang berumur 2-3 tahun bisa tahan mengenakan masker terus-menerus selama berjam-jam sehingga terdapat tahapantahapannya. Ketika anak mulai bosan, keluarga bisa menguatkan dengan kata-kata persuasive seperti "dengan pakai masker bisa melindungi diri sendiri serta keluarga sekitar, seperti kakek nenek yang satu rumah, jadi anak bisa menjadi pahlawan super". Atau menganti alternative lain seperti mengganti masker dengan alat pelindung wajah (face shields)(UNICEF \& WHO, 2020). Selain masker, satgas juga menyebutkan protokol kesehatan lain yang harus diajarkan kepada anak yaitu kegiatan mencuci tangan. Dimana WHO menganjurkan 20 detik untuk mencuci tangan. Agar anak tidak bosan maka bisa sambil bernyanyi lagu anak selama mencuci tangan,".

Dengan menjelaskan dan melakukan pembiasaan pada protokol kesehatan seperti penggunaan masker dan mencuci tangan bisa menanamkan rasa tanggungjawab, jujur, disiplin, mandiri dan religius pada anak. Hal tersebut didukung oleh penelitian oleh 
Nugrahani et al. (2019) yang hasilnya menunjukkan untuk mengajarkan karakter pada anak yaitu dimulai dengan pemahaman, penanaman nilai karakter, dilanjutkan dengan pelaksanaannya melalui pembiasaan, dan budaya, sehingga membentuk nilai-nilai yang ada yang ditangani dapat tercermin dalam sikap dan perilaku sehari-hari.

Dengan paham tentang apa itu virus covid-19 dan bahaya pada kesehatan maka anak memiliki rasa tanggung jawab memakai masker atau alat pelindung wajah. Mandiri dalam melakukan aktivitas seperti mencuci tangan, disipiln bangun pagi untuk berolahraga dan berjemur, jujur akan aktivitas yang telah dilakukan seperti sudah mencuci tangan dan mandi dan religius seperti berdoa kepada allah untuk selalu diberikan kesehatan atau mengajarkan anak tetang adab berperilaku seperti penelitian yang oleh Abdusshomad, (2020) Terdapat hikmah dengan kejadian Covid-19 ini yaitu dalam membantu seseorang untuk bisa mengingat kembali dan menerapkan pendidikan karakter dan pendidikan Islam yang mana telah banyak terlupakan, pendidikan karakter dan pendidikan Islam tersebut di antaranya seperti etika menutup hidung dan mulut ketika bersin, menutup mulut ketika batuk, menutup mulut ketika menguap, etika berbicara, menjaga kebersihan, dan kesehatan.

\section{SIMPULAN}

Grandparenting merupakan suatu aktivitas merawat, mengasuh dan mendidik cucu dalam kelangsungan hidupnya. Dari hasil penelitian menunjukkan penyerahan pengasuhan pada nenek terjadi akibat beberapa faktor yaitu perceraian, kematian dan waktu bekerja orang tua yang harus melimpahkan tanggung jawab mengasuh kepada nenek. Pola pengasuhan yang di gunakan nenek berupa pengasuhan yang otoriter, otoritatif dan permissive dengan menggunakan metode penjelasan, pemberian contoh dan pembiasaan. Dalam pola asuh yang digunakan nenek berdampak baik dalam membentuk karakter berupa disiplin, tanggung jawab, jujur, religius dan mandiri pada cucu mereka. Dengan terbentuknya karakter anak dengan baik maka dalam membiasakan anak dalam menerapkan protokol kesehatan dengan hidup bersih dan sehat juga berjalan dengan baik pula.

\section{UCAPAN TERIMA KASIH}

Ucapan terima kasih peneliti sampaikan kepada semua responden (nenek dan keluarga), guru TK di Kabupaten Ogan Komering Ilir (OKI), Kabupaten Ogan Ilir (OI), Kabupaten Ogan Komering Ulu Selatan (OKUS), Kabupaten Ogan Komering Ulu Timur (OKUT) dan Kabupaten Ogan Komering Ulu (OKU) yang telah memberikan support hingga terselesaikan penelitian ini.

\section{DAFTAR PUSTAKA}

Abdusshomad, A. (2020). Pengaruh Covid-19 terhadap Penerapan Pendidikan Karakter dan Pendidikan Islam. Qalamuna - Jurnal Pendidikan, Sosial, Dan Agama, 12(2), 107-115. https:// doi.org/10.37680/qalamuna.v12i2.407

Alyami, M. (2020). Guidance for Corona Virus Disease 2019. Printed In People's Republic Of China. http://www.pmph.com/

Arini, S. (2018). Pola Asuh, Pengasuhan Kakek-Nenek, Jarak Antar Generasi, Sifat Anak, Prestasi Anak. Jurnal Demensia, 7(1), 98-114.

Breheny, M., Stephens, C., \& Spilsbury, L. (2013). Involvement without interference: How grandparents negotiate intergenerational expectations in relationships with grandchildren. Journal of Family Studies, 19(2), 174-184. https://doi.org/10.5172/jfs.2013.19.2.174

Cristea, A. (2016). Pola Asuh Grand Parenting (Studi pada 5 keluarga di Desa Wukirsari Imogiri, Bantul). Revista Brasileira de Ergonomia, 9(2), 10. https://www.infodesign.org.br/infodesign/article/view/355\%0Ahttp://www.aber go.org.br/revista/index.php/ae/article/view/731\%0Ahttp://www.abergo.org.br/r evista/index.php/ae/article/view/269\%0Ahttp://www.abergo.org.br/revista/inde 
x.php/ae/article/view/106

Delap, E., Mann, G., \& Frontiers, C. (2020). Prioritising support to kinship care in responses to COVID-19 (Issue May).

Edwards, O. W. (2018). School perceptions of children raised by grandparents. Journal of $\begin{array}{llll}\text { Applied School } & \text { Psychology, 86-100. }\end{array}$ https:/ / doi.org/10.1080/15377903.2017.1403401

Eriyanti, ishvi oktavenia, Susilo, H., \& Riyanto, Y. (2019). Analisis Pola Asuh Grandparenting Dalam Pembentukan Karakter Anak Di Tk Dharma Wanita I Desa Drokilo Kecamatan Kedungadem Kabupaten Bojonegoro. Jurnal Pendidikan Untuk Semua, 3(1), 9-16.

Fauziningtyas, R., Indarwati, R., Alfriani, D., Haryanto, J., Ulfiana, E., Efendi, F., Nursalam, N., \& Abdullah, K. L. (2019). The experiences of grandparents raising grandchildren in Indonesia. Working with Older People, 23(1), 17-26. https:// doi.org/10.1108/WWOP10-2018-0019

Fono, Y. M., Fridani, L., \& Meilani, S. M. (2019). Kemandirian dan Kedisplinan Anak yang Diasuh oleh Orangtua Pengganti. Jurnal Obsesi : Jurnal Pendidikan Anak Usia Dini, 3(2), 537. https://doi.org/10.31004/obsesi.v3i2.245

Gupta, M., \& Mehtani, D. (2017). Construction and Validation of Parenting Style Scale (PSS). Shikshan Anveshika, 7(1), 1. https:// doi.org/10.5958/2348-7534.2017.00001.0

Khadijahalavi, Dorisdagang, \& Muhammadsaleem. (2016). Empowering Grandparenting Style a Family Based. April, 11-17.

Lasota, A. (2015). What do Children Learn from their Parents and what from their Grandparents? Changes in the Perception of Gender and Family Roles as Seen from the Developmental Perspective. Procedia - Social and Behavioral Sciences, 174, 2467-2472. https:// doi.org/10.1016/j.sbspro.2015.01.918

Latifah, E. W., Krisnatuti, D., \& Puspitawati, H. (2016). Pengaruh pengasuhan ibu dan nenek terhadap perkembangan kemandirian dan kognitif anak usia prasekolah. Jur. Ilm. Kel. $\mathcal{E}$ Kons., 9(1), 21-32.

Muncsh, L. E. L. \& J. (2016). Child Development Form Infancy To Adolescence (An Active Learning Approach) (Thousand O). SAGE Publications.

Nugrahani, F., Widayati, M., \& Imron, A. (2019). Strengthening Character Education in Elementary School. 971-979. https://doi.org/10.4108/eai.3-11-2018.2285653

Nurlatifah, N. N., Rachmawati, Y., \& Yulindrasari, H. (2020). Pendidikan karakter anak usia dini pada keluarga tanpa ayah. Edukid, 17(1), 42-49. https:// doi.org/10.17509/edukid.v17i1.24213

Presiden Republik Indonesia. (2017). Perpres no. 87 Tahun 2017. 6 September 2017. https:/ / setkab.go.id/inilah-materi-perpres-no-87-tahun-2017-tentang-penguatanpendidikan-karakter/

Purandina, I. P. Y., \& Winaya, I. M. A. (2020). Pendidikan Karakter di Lingkungan Keluarga Selama Pembelajaran Jarak Jauh pada Masa Pandemi COVID-19. Cetta: Jurnal Ilmu Pendidikan, 3(2), 270-290. https://doi.org/https://doi.org/10.37329/cetta.v3i2.454

Putri, A. D., \&, \& Izzati. (2020). Pelaksanaan Perkembangan Kemandirian Anak yang Diasuh oleh Grandparent. 4, 1269-1277.

Salafuddin, Santosa, Utomo, S., \& Utaminingsih, S. (2020). Pola Asuh Orang Tua dalam Penguatan Pendidikan Karakter Anak (Studi Kasus pada Anak TKW di SDN Pidodo Kecamatan Karangtengah). JPAI: Jurnal Perempuan Dan Anak Indonesia, 2(1), 18. https:// doi.org/10.35801/jpai.2.1.2020.28276

Samiaji, M. H. (2019). Perkembangan Karakter Mandiri dan Jujur Pada Anak Usia Dini (Studi Kasus Anak-Anak KB Wadas Kelir Purwokerto Selatan). ThufuLA: Jurnal Inovasi Pendidikan Guru Raudhatul Athfal, 7(2), 295-308. https:// doi.org/10.21043/thufula.v7i2.6490

Santi, L. (2016). The Habituations Of Behavior As Student Character Reinforcement In Global Era. 2(93), 414-428. https://doi.org/http://dx.doi.org/10.15575/jpi.v2i3.852 
DOI: 10.31004/obsesi.v5i2.831

Santoso, S. T. P., \& Fahrinnia, V. (2018). Mom Worked: Patterns of Parenting and Attachment by Children. Atlantic, 244(Ecpe), 189-192. https://doi.org/10.2991/ ecpe-18.2018.42

Sary, Y. N. E. (2020). Cara Asuh Nenek pada Anak Usia Dini di Masa Pandemi Covid-19. Jurnal Obsesi: Jurnal Pendidikan Anak Usia Dini, 5(1), 327-333. https://doi.org/10.31004/obsesi.v5i1.585

Saxena, D., \& Sean, B. (2019). Grandparents When Parents to Their Become Grandchildren. In Journal of Chemical Information and Modeling (Vol. 53, Issue 9).

Sulistyawati, L., \& Murdaningsih, D. (2020). Cara Asyik Ajarkan Protokol Kesehatan kepada Anak. Republika.Co.Id.

Sumargi, A., Sofronoff, K., \& Morawska, A. (2015). Understanding parenting practices and parents' views of parenting programs: A survey among Indonesian parents residing in Indonesia and Australia. Journal of Child and Family Studies, 24(1), 144-160. https://doi.org/. https://doi.org/10.1007/s10826-013- 9821-3

Suprapto, R., Hayati, M., Nurbaity, S., Anggraeni, F., Haritsatama, S., Sadida, T. Q., Firoh, A., \& Pratama, F. A. (2020). Pembiasaan Cuci Tangan yang Baik dan Benar pada Siswa Taman Kanak-Kanak (TK) di Semarang. Jurnal Surya Masyarakat, 2(2), 139. https://doi.org/10.26714/jsm.2.2.2020.139-145

Susanti, S. (2017). Jurnal Psikologi Konseling Vol. 11 No.2, Desember 2017. 11(2), 1-13.

UNICEF \& WHO. (2020). Advice on the use of masks in the context of COVID-19. Who, April, $1-5$.

Wellard, S. (2011). Too Old to Care? The experiences of older grandparents raising their grandchildren. Grandparents Plus, 1-50.

Yun, B. X., Thing, T. S., \& Hsoon, N. C. (2019). A Quantitative Study of Relationship between Parenting Style and Adolescent's Self-esteem. 304(Acpch 2018), 441-446. https://doi.org/10.2991/acpch-18.2019.103 